\title{
Smoking Methods and Their Effects on Nutritional Value of African Catfish (Clarias gariepinus)
}

\author{
M. O. Aremu ${ }^{\mathrm{a}, *}$, S. B. Namo ${ }^{\mathrm{b}}$, R. B. Salau', C. O. Agbo ${ }^{\mathrm{d}}$ and H. Ibrahim ${ }^{\mathrm{b}}$ \\ ${ }^{a}$ Department of Chemical Sciences, Federal University Wukari, PMB 1020, Taraba State, Nigeria \\ ${ }^{b}$ Department of Chemistry, Nasarawa State University, PMB 1022, Keffi, Nigeria \\ ${ }^{c}$ Department of Chemistry, Universiti Teknologi, Malaysia/Department of Chemistry, Federal University of Technology, \\ Minna, Nigeria \\ ${ }^{d}$ Department of Chemistry, Federal University of Agriculture, Makurdi, Nigeria
}

\begin{abstract}
African catfish (Clarias gariepinus) is very popular with fish farmers and consumers, and commands a very high commercial value in Nigeria markets. The fresh fish sample collected from the fish farmer was smoked in a smoking kiln using sawdust, rice bran and melon husk while electric oven was used as the control. In the study proximate, mineral and amino acid compositions of the smoked fish samples were evaluated using standard analytical techniques. The crude protein content of the smoked fish samples ranged from $15.18 \%$ in sawdust heat treatment to $63.23 \%$ in electric oven heat source with CV\% of 10.68 while crude fat range values were $9.47-16.44 \%(\mathrm{CV} \%=18.80)$. The most highly concentrated mineral was sodium (7.00 - $9.95 \mathrm{mg} / 100 \mathrm{~g}$ sample) and strictly followed by magnesium (5.45 - $7.45 \mathrm{mg} / 100 \mathrm{~g}$ sample). Lead and cadmium were not at the detectable range of AAS. The total essential amino acid (TEAA) with histidine in the smoked fish samples ranged from $40.25 \mathrm{~g} / 100 \mathrm{~g}$ crude protein in rice bran to $70.09 \mathrm{~g} / 100 \mathrm{~g}$ protein in sawdust heat sources while lysine had the highest concentrations (7.02 - $7.78 \mathrm{~g} / 100 \mathrm{~g}$ protein). The calculated isoelectric point (pI) and predicted protein efficiency ratio (P-PER) were $(4.99-6.91)$ and $(2.30-2.52)$, respectively while first limiting amino acid (LAA) was isoleucine for electric oven and sawdust heat sources, and valine for melon husk and rice bran smoking. The number of essential amino acids where supplementation may be required in the smoked fish samples using four different heat sources was three each. Generally, all the fish samples were found to be good sources of essential minerals and amino acids.
\end{abstract}

Keywords: African catfish, smoking, chemical composition.

\section{INTRODUCTION}

Fish has an important role in food security and poverty alleviation in both rural and urban areas of Nigeria, but only little is known about the nutritional value of the fishes that are normally utilized either fresh or preserve dried, salted or smoked. However, fish is an extremely perishable commodity, spoiling soon after death, due to enzymatic and microbial actions. Some factors responsible for this include the prevailing high temperatures in Nigeria and the facilities for processing, storing and distributing the fish caught are frequently inadequate or non-essential in most cases. There is therefore enormous waste through spoilage of both fresh and dried fish $[1,2]$. Fish is smoked until cooked in order to obtain a product with extended shelf-life, since alternative preservation methods such as refrigeration are absent in remote fishing villages where most fish processing takes place. Hot smoking is the traditional methods of fish smoking in the

*Address correspondence to this author at the Department of Chemical Sciences, Federal University Wukari, PMB 1020, Taraba State, Nigeria; Tel: +2348065611658; E-mail: lekearemu@gmail.com tropics. Hot smoking entails the application of much more heat, through the burning of large quantity of fuel-wood [3]. The products from hot smoking are tastier and have longer shelf lives [4, 5]. Smoking preserves fish by drying, cooking and depositing natural wood-smoke chemicals like tars, phenols and aldehydes all of which have powerful bactericidal action and prevent the growth of other microorganisms on the flesh of the fish [6]. The smoke determines the colour which is one of the qualities that attracts consumers. The colour of smoked fish is relatively not independent on the method as well as the type of wood or agricultural waste used in smoking the fish. The colour ranges from black, dark brown, golden brown or light brown to dirty white [3]. Although preservation methods for fish and products are often used in order to make the fish safer and to prolong its shelflife, the determination of some proximate parameters such as moisture, ash, lipid and protein contents are necessary so as to ascertain that they meet the requirements of food regulations and commercial specifications [7-9].

African catfish (Clarias gariepinus) of the family Claricdae, is generally considered to be one of the most important tropical catfish species for aquaculture. It has an al- 
most Pan-African distribution, ranging from the Nile to West Africa and from Algeria to Southern Africa, up to the Mediterranean coast including Asian Minor. It is a slowmoving omnivorous predatory fish, which feeds on a variety of food items from microscopic zooplankton to fish half its length or $10 \%$ of its own body weight [10]. African catfish is of very high demand in the middle belt and north east of $\mathrm{Ni}$ geria on account of their tasty flesh $[7,11]$. The species are very popular with fish farmers and consumers, and they command a very high commercial value in Nigeria markets $[12,13]$.

The objective of the present study was to assess the efficiency of traditional smoking methods using different heat sources, such as sawdust, melon husk and rice bran and electric oven (control), for changing the chemical composition of African catfish (Clarias gariepinus) with a view to providing preliminary information towards effective utilization of African catfish in various food applications in Africa.

\section{MATERIALS AND METHODS}

\section{Sample Collection and Treatment}

Fresh sample (8 kg) of African catfish (Clarias gariepinus) was purchased from a fish farmer by a river site in Akwanga town of Nasarawa State, Nigeria in April, 2012. The sample was brought into the laboratory and divided into four equal portions about $2 \mathrm{~kg}$ each. The first portion was dried in an electric oven at about $60^{\circ} \mathrm{C}$ for $24 \mathrm{~h}$ using it as control while the other three portions were smoked in a smoking kiln using sawdust, melon husk and rice bran at different times, respectively. The dried samples were blended separately into fine powder using Kenwood food blender. The powdered portion was put in a plastic container and kept in a refrigerator at about $4^{\circ} \mathrm{C}$ prior to use.

\section{Proximate Analyses}

The moisture, ash, crude fat, crude protein $(\mathrm{N} \times 6.25)$, crude fibre and carbohydrate (by difference) were determined in accordance with AOAC methods [14]. All proximate analyses of the fish sample flours were carried out in triplicate and reported in percent [15]. All chemicals were of Analar grade.

\section{Mineral Analysis}

The minerals were analysed from solutions obtained by first dry-ashing the fish samples at $550^{\circ} \mathrm{C}$ and dissolving the ash in distilled deionized water in flasks [16]. All the metals (except $\mathrm{Na}$ and $\mathrm{K}$ ) were determined by using atomic absorption spectrophotometer (Perkin-Elmer Model 403, Norwalk $\mathrm{CT}$ ). Sodium and potassium were determined using a flame photometer (Corning, UK Model 405), while $\mathrm{NaCl}$ and $\mathrm{KCl}$ were used to prepare the standards [15]. Phosporus was determined by vanadomolybdate colourimetric method [17].

\section{Amino Acid Analysis}

The amino acids in the fish samples were analysed by ion exchange chromatography (IEC) [18] using the Technicon Sequential Multisample (TSM) Amino Acid Analyzer (Technicon Instruments Corporation, New York). The period of analysis was 76 min for each sample. The gas flow rate was $0.50 \mathrm{~mL} \mathrm{~min}^{-1}$ at $60^{\circ} \mathrm{C}$ with reproducibility consistent within $\pm 3 \%$. The net height of each peak produced by the chart recorder of the TSM (each representing an amino acid) was measured and calculated. The amino acid values reported were the averages of two determinations [16]. Norleucine was the internal standard. Tryptophan was not determined.

\section{Determination of Quality Parameters}

Determination of isoelectric point (pI): The predicted isoelectric point was evaluated as follows [19].

$p \operatorname{Im}=\sum_{i=1}^{n=1} p I i X i$

Where pIm is the isoelectric point of the mixture of amino acids, $\mathrm{pI}_{\mathrm{i}}$ is the isoelectric point of the $\mathrm{i}^{\text {th }}$ amino acids in the mixture and $X_{\mathrm{i}}$ is the mass or mole fraction of the amino acids in the mixture.

\section{Determination of Amino Acid Scores}

Amino acid scores were determined based on whole hen's egg [20]. In this method, essential amino acids were scored, Met + Cys and Phe + Tyr were taken as a unit while amino acid score (AAS) was calculated using the following formula [21].

\section{Determination of the Predicted Protein Efficiency Ratio}

The predicted protein efficiency ratio (P-PER) of differently processed samples was calculated from their amino acid composition based on the following equation [22]:

$$
\text { P-PER }=-0.468+0.454 \text { (Leu) }-0.105 \text { (Tyr) }
$$

\section{Calculations and Statistical Analyses}

Sodium/potassium $(\mathrm{Na} / \mathrm{K})$ and calcium/phosphorus $(\mathrm{Ca} / \mathrm{P})$ ratios were calculated for the samples [23]. The fatty acid values were obtained by multiplying crude fat value of each sample with a factor of 0.8 (i.e. crude fat $\times 0.8=$ corresponding to fatty acids value) [24]. The energy values were calculated by adding up the carbohydrate $\times 17 \mathrm{~kJ}$, crude protein $\times 17 \mathrm{~kJ}$ and crude fat $\times 37 \mathrm{~kJ}$ for each of the samples [25]. Standard deviations were calculated using MS Excel Spread sheet from the three determinations done on each sample for the proximate composition and it was used as the measure of dispersion.

\section{RESULTS AND DISCUSSION}

The result of proximate composition of smoked Clarias gariepinus is shown in Table $\mathbf{1}$. The protein content (68.18\%) of the fish sample smoked with melon husk was the highest while the sample smoked using sawdust was the lowest (51.18\%). However, the range from 51.18 to $68.18 \%$ in this report is in agreement with the reported work on catfish [26]. The protein content of $57.03 \%$ obtained by using rice bran heat treatment agrees with the $56.9 \%$ reported for Tilapia quineensis [27]. The fat content for the sample smoked with sawdust is highly comparable with $13.55 \%$ 
Table 1. Proximate Composition (\%) of Clarias gariepinus Smoked with Different Sources of Heat

\begin{tabular}{|c|c|c|c|c|c|c|c|}
\hline \multirow{2}{*}{ Parameter } & \multicolumn{4}{|c|}{ Heat Treatments } & \multirow{2}{*}{ Mean } & \multirow{2}{*}{ SD } & \multirow{2}{*}{ CV\% } \\
\hline & Electric Oven & Sawdust & Melon Husk & Rice Bran & & & \\
\hline Protein & $63.23 \pm 0.01$ & $51.18 \pm 0.08$ & $68.18 \pm 0.06$ & $57.03 \pm 0.10$ & 59.91 & 6.40 & 10.68 \\
\hline Fat & $13.55 \pm 0.02$ & $13.31 \pm 0.30$ & $9.47 \pm 0.07$ & $16.44 \pm 0.04$ & 13.19 & 2.48 & 18.80 \\
\hline Crude fibre & $7.16 \pm 0.04$ & $15.63 \pm 0.04$ & $11.68 \pm 0.08$ & $11.48 \pm 0.03$ & 11.49 & 3.00 & 26.12 \\
\hline Moisture & $3.57 \pm 0.03$ & $4.46 \pm 0.13$ & $3.77 \pm 0.06$ & $3.18 \pm 0.12$ & 3.75 & 0.46 & 12.27 \\
\hline Ash & $5.14 \pm 0.04$ & $3.18 \pm 0.02$ & $3.37 \pm 0.05$ & $4.18 \pm 0.05$ & 3.97 & 0.77 & 19.40 \\
\hline${ }^{\mathrm{b}}$ Carbohydrate & $2.54 \pm 0.03$ & $2.46 \pm 0.16$ & $1.26 \pm 0.05$ & $2.11 \pm 0.09$ & 2.09 & 0.51 & 24.40 \\
\hline${ }^{\mathrm{c}}$ Fatty acid & 10.84 & 10.65 & 7.58 & 13.15 & 42.22 & 31.73 & 75.15 \\
\hline dEnergy (kJ/100g) & 1619.44 & 1404.35 & 1530.87 & 1613.66 & 1542.08 & 86.90 & 5.64 \\
\hline
\end{tabular}

${ }^{\mathrm{a}}$ Each value represents the mean \pm standard deviation of triplicate determinations; ${ }^{\mathbf{b}}$ Carbohydrate percent calculated as the (100 - total other components); 'Calculated fatty acids ( 0.8 x crude fat); ${ }^{\mathrm{d} C}$ Calculated metabolisable energy (kJ/100g) (protein x $17+$ fat x 37 + carbohydrate x 17);

SD = Standard deviation; $\mathbf{C V}=$ Coefficient of variation.

obtained for electric oven smoking however, it is lower than the reported values of $19.80 \%$ to $23.90 \%$ for smoked Clarias gariepinus from Lagos State University (Nigeria) fish pond and Badagry market, respectively [28]. The crude fibre content of 7.16\% obtained for fish sample smoked with an electric oven is less than the values obtained for sawdust, rice bran and melon husk heat treatments, and the range from $7.16 \%$ to $15.63 \%$ reported in this work are higher than the values presented in catfish [26]. The fish sample smoked with sawdust had the highest moisture content of $4.46 \%$ in this report. However, the $3.57 \%$ value for smoked sample in an electric oven is in close agreement with the sample values for melon husk and rice bran heat treatments. The range between $3.18 \%$ and $4.46 \%$ is lower than those reported in raw and dried catfish by some authors [26]. The moisture content of $4.46 \%$ for the fish sample smoked using sawdust compares favourably with $4.55 \%$ for Caesalpinia pulcherrima [29]. The ash content of 5.14\% obtained using electric oven smoking in this report was the highest while the sample smoked with sawdust had the lowest ash content. The calculated metabolizable energy which ranged between 1404.35 $\mathrm{kJ} / 100 \mathrm{~g}$ in sawdust heat treatment to $1619.44 \mathrm{~kJ} / 100 \mathrm{~g}$ in electric oven drying showed that Clarias gariepinus is favourably comparable to Tilapia quineensis [27] in terms of its energy value. The calculated fatty acid values ranged between $7.58 \%$ in melon husk heat treatment to $13.15 \%$ in rice bran heat treatment. Crude fibre recorded the highest value of CV\% (26.12). The carbohydrate content (2.46\%) of the sample smoked with sawdust was the highest. The ranged values of $1.26 \%$ to $2.54 \%$ are lower than that for some plants food [30].

The mineral composition in $\mathrm{mg} / 100 \mathrm{~g}$ of Clarias gariepinus is presented in Table 2 . The most abundant mineral in the smoked fish samples was sodium which ranged between 7.00 to $9.95 \mathrm{mg} / 100 \mathrm{~g}$ sample. This is followed by magnesium with range values of 5.45 to $7.45 \mathrm{mg} / 100 \mathrm{~g}$ while the least concentrated mineral was chromium $(0.15$ to 0.45 $\mathrm{mg} / 100 \mathrm{~g})$. It is interesting to note that harmful lead and cadmium were not at the detectable range of AAS in all the smoked fish samples. Lead even at low concentration is known to be toxic and has no known function in biochemical process [31]. Arenic and chromium were not also detected in the fish samples smoked with melon husk and sawdust, respectively. The values in $\mathrm{mg} / 100 \mathrm{~g}$ sample of other essential minerals in the smoked fish samples were; potassium ranged between 5.15 to $6.50 \mathrm{mg} / 100 \mathrm{~g}$ sample, phosphorus (4.10 to $5.55 \mathrm{mg} / 100 \mathrm{~g}$ ), manganese (2.45 to $4.55 \mathrm{mg} / 100 \mathrm{~g}$ ) and calcium (1.15 to $3.30 \mathrm{mg} / 100 \mathrm{~g})$. Calcium in junction with phosphorus, magnesium, vitamin $\mathrm{A}, \mathrm{C}$ and $\mathrm{D}$, chlorine and protein are all involved in bone formation [32]. Calcium is also important in blood clotting, muscles contraction and in certain enzymes in metabolic processes [33]. Magnesium is an important activator of many enzymes system and maintains the electrical potential in nerves [33]. Phosphorus assists calcium in many body reactions, although it has independent functions. Modern diets that are rich in animal proteins and phosphorus may promote the loss of calcium in the urine [34]. This has led to the concept of the calcium to phosphorus ratio. If the calcium to phosphorus ratio is low (low calcium, high phosphorus intake) more than the normal amount of calcium may be lost in the urine thereby decreasing the calcium level in bones. Food is considered "good" if the $\mathrm{Ca} / \mathrm{P}$ ratio is above 1 and "poor" if the ratio is less than 0.5 , while the $\mathrm{Ca} / \mathrm{P}$ ratio above 2 helps to increase the absorption of cadmium in the small intestine. The result of $\mathrm{Ca} / \mathrm{P}$ ratio in the smoked fish samples of present study was greater than 0.5 i.e. 0.52 to 0.66 . The sodium to potassium ratio of less than 1 is recommended for the prevention of high blood pressure [23]. However, the smoked samples of Clarias gariepinus in the current study may not be able to prevent high blood pressure because the value for $\mathrm{Na} / \mathrm{K}$ ratio is greater than 1 . Coefficient of variation percent (CV\%) levels of all the minerals were also relatively close with the highest value found in chromium (56.0) while the lowest found in calcium to phosphorus ratio (8.62). In order to prevent a disease known as hypomagnesaemia, the milliequivalent of $[\mathrm{K} /(\mathrm{Ca}+\mathrm{Mg})]$ in food sample must be less than 2.2 [35]. The range values from 0.55 to 0.82 in all the fish sam- 
Table 2. Mineral Composition (mg/100g) of Clarias gariepinus Smoked with Different Sources of Heat

\begin{tabular}{|c|c|c|c|c|c|c|c|}
\hline \multirow{2}{*}{ Mineral } & \multicolumn{4}{|c|}{ Heat Treatments } & \multirow{2}{*}{ Mean } & \multirow{2}{*}{ SD } & \multirow{2}{*}{ CV\% } \\
\hline & Electric Oven & Sawdust & Melon Husk & Rice Bran & & & \\
\hline $\mathrm{Na}$ & 7.15 & 8.35 & 7.00 & 9.95 & 8.11 & 1.8 & 14.55 \\
\hline K & 5.15 & 6.50 & 6.25 & 6.45 & 5.84 & 0.55 & 9.42 \\
\hline $\mathrm{Mg}$ & 6.10 & 7.45 & 5.45 & 6.15 & 6.29 & 0.73 & 11.61 \\
\hline $\mathrm{Fe}$ & 1.75 & 3.20 & 0.60 & 2.15 & 1.93 & 0.93 & 48.19 \\
\hline $\mathrm{Zn}$ & 1.30 & 1.20 & 2.05 & 1.45 & 1.50 & 0.33 & 22.00 \\
\hline $\mathrm{Cu}$ & 0.54 & 0.56 & 0.51 & 0.78 & 0.60 & 0.11 & 18.33 \\
\hline $\mathrm{Pb}$ & ND & ND & ND & ND & ND & ND & ND \\
\hline As & 0.10 & 0.45 & ND & 0.35 & 0.30 & 0.15 & 50.00 \\
\hline $\mathrm{Cr}$ & 0.15 & ND & 0.45 & 0.15 & 0.25 & 0.14 & 56.00 \\
\hline Cd & ND & ND & ND & ND & ND & ND & ND \\
\hline Mn & 4.55 & 2.80 & 2.45 & 3.80 & 3.40 & 0.83 & 24.41 \\
\hline $\mathrm{Ca}$ & 3.30 & 2.45 & 2.15 & 3.05 & 2.74 & 0.46 & 16.79 \\
\hline $\mathrm{P}$ & 5.55 & 4.45 & 4.10 & 4.65 & 4.69 & 0.54 & 11.51 \\
\hline $\mathrm{Na} / \mathrm{K}$ & 1.39 & 1.28 & 1.12 & 1.83 & 1.41 & 0.26 & 18.44 \\
\hline $\mathrm{Ca} / \mathrm{P}$ & 0.59 & 0.55 & 0.52 & 0.66 & 0.58 & 0.05 & 8.62 \\
\hline$[\mathrm{K} /(\mathrm{Ca}+\mathrm{Mg})]$ & 0.55 & 0.66 & 0.82 & 0.59 & 0.66 & 0.10 & 15.15 \\
\hline
\end{tabular}

$\mathbf{N a / K}$ = Sodium to potassium ratio; $[\mathbf{K} /(\mathbf{C a}+\mathbf{M g})]$ = Potassium to sum of calcium to magnesium; ND = Not detected; SD = Standard deviation; $\mathbf{C V}=$ Coefficient of variation.

ples are less than 2.2 therefore they may not lead to hypomagnesaemia.

The amino acid composition of smoked Clarias gariepinus is presented in Table 3 . It is observed that glutamic and aspartic acids were the most abundant amino acids in all the smoked fish samples and make up to values which ranged between 12.87 to $14.24 \mathrm{~g} / 100 \mathrm{~g}$ crude protein (cp) and 8.93 to $9.71 \mathrm{~g} / 100 \mathrm{~g}$ cp, respectively. Similar observation has been reported [36, 37]. Lysine which ranged between 7.02 to 7.78 $\mathrm{g} / 100 \mathrm{~g}$ cp was the most concentrated essential amino acid followed by leucine with range values of $6.80 \mathrm{~g} / 100 \mathrm{~g} \mathrm{cp}$ in rice bran heat treatment to $7.32 \mathrm{~g} / 100 \mathrm{~g} \mathrm{cp}$ in electric oven (control) smoking. Arginine is essential for children growth and reasonable levels were present in this report. The lysine contents of the samples are slightly above the $6.3 \mathrm{~g} / 100 \mathrm{~g}$ content of the reference egg protein. This signifies that the fish samples will serve as good sources for fortification of protein weaning foods. Histidine which ranged between 2.30 $\mathrm{g} / 100 \mathrm{~g}$ cp for sample smoked using rice bran to $2.71 \mathrm{~g} / 100 \mathrm{~g}$ cp for electric oven smoking is a semi essential amino acid particularly useful for children growth. It is the precursor of histamine present in small quantities in cells. When allergens enter the tissues, it is liberated in larger quantities and is responsible for nettle rash [38]. The values of isoleucine ranged between 3.55 to $3.80 \mathrm{~g} / 100 \mathrm{~g}$ cp in the smoked fish samples. The isoleucine is an essential amino acid for both old and young. Maple syrup urine disease is an inborn error of metabolism in which brain damage and early death can be avoided by a diet low in isoleucine and two other essential amino acids, leucine and valine. These three EAA were high in the current report. Methionine (CV\%, 2.08) is an essential amino acid (EAA) with value range of 2.32 to $2.45 \mathrm{~g} / 100 \mathrm{~g}$ cp or 3.18 to $3.38 \mathrm{~g} / 100 \mathrm{~g}$ cp with cystine (Table 4). Methionine is needed for the synthesis of chlorine from lecithin and other phospholipids in the body. When the diet is low in protein, for instance in alcoholism and kwashiorkor, insufficient chlorine may be formed; this may cause accumulation of fat in the liver. Phenylalanine values ranged between 3.71 $\mathrm{g} / 100 \mathrm{~g}$ cp for rice bran heat treatment to $31.88 \mathrm{~g} / 100 \mathrm{~g}$ cp for sawdust smoking. It is the precursor of some hormones and the pigment melanin in hair, eyes and tanned skin. Phenylketonuria is the commonest inborn error of metabolism successfully treated by diet. The absence of enzymes in the liver blocks the normal metabolism of phenylalanine and the brain is irreversibly damaged unless a diet low in phenylalanine is given in the first few weeks of life [38]. Tyrosine value in this report ranged from 3.02 to $3.17 \mathrm{~g} / 100 \mathrm{~g}$ cp. Tyrosine is the precursor of some hormones (like the thyroid hormones) and the brown pigment melanine formed in hair, eyes and tanned skin. It reduces the requirement of phenylalanine. Permanent deficiency of the enzyme hypertyrosinaemia, a rare in born error of metabolism can cause liver and kidney failure unless treated with a synthetic diet low in phenylalanine and tyrosine [38]. The predicted protein efficiency 
Table 3. Amino Acid Composition (mg/100g Crude Protein) of Clarias gariepinus Smoked with Different Sources of Heat

\begin{tabular}{|c|c|c|c|c|c|c|c|}
\hline \multirow{2}{*}{ Amino Acid } & \multicolumn{4}{|c|}{ Heat Treatments } & \multirow{2}{*}{ Mean } & \multirow{2}{*}{ SD } & \multirow{2}{*}{ CV\% } \\
\hline & Electric Oven & Sawdust & Melon Husk & Rice Bran & & & \\
\hline Lysine (Lys) ${ }^{\mathrm{a}}$ & 7.78 & 7.40 & 7.21 & 7.02 & 7.35 & 0.28 & 3.81 \\
\hline Histidine (His) ${ }^{\mathrm{a}}$ & 2.71 & 2.62 & 2.62 & 2.30 & 2.54 & 0.15 & 5.91 \\
\hline Arginine (Arg) $)^{\mathrm{a}}$ & 6.39 & 6.30 & 5.87 & 5.78 & 6.09 & 0.26 & 4.27 \\
\hline Aspartic acid (Asp) & 9.68 & 9.71 & 8.93 & 9.30 & 9.41 & 0.32 & 3.40 \\
\hline Threonine (Thr) ${ }^{\mathrm{a}}$ & 4.69 & 4.30 & 4.00 & 4.28 & 4.32 & 0.25 & 5.79 \\
\hline Serine (Ser) & 4.39 & 4.01 & 4.34 & 4.01 & 4.19 & 0.18 & 4.30 \\
\hline Glutamic acid (Glu) & 14.24 & 13.33 & 12.87 & 13.02 & 13.37 & 0.53 & 3.96 \\
\hline Proline (Pro) & 4.27 & 3.66 & 3.46 & 3.25 & 3.66 & 0.38 & 10.38 \\
\hline Glycine (Gly) & 7.01 & 6.39 & 6.29 & 5.50 & 6.30 & 0.54 & 8.57 \\
\hline Alanine (Ala) & 6.23 & 6.00 & 5.85 & 5.89 & 5.99 & 0.15 & 2.50 \\
\hline Cystine (Cys) & 0.93 & 0.93 & 0.86 & 0.86 & 0.90 & 0.04 & 4.44 \\
\hline Valine $(\mathrm{Val})^{\mathrm{a}}$ & 4.81 & 4.60 & 3.99 & 4.31 & 4.43 & 0.31 & 7.00 \\
\hline Methionine (Met) ${ }^{\mathrm{a}}$ & 2.45 & 2.42 & 2.32 & 2.40 & 2.40 & 0.05 & 2.08 \\
\hline Isoleucine (Ile) $)^{\mathrm{a}}$ & 3.80 & 3.55 & 3.65 & 3.65 & 3.66 & 0.09 & 2.46 \\
\hline Leucine (Leu) ${ }^{\mathrm{a}}$ & 7.32 & 7.02 & 7.20 & 6.80 & 7.09 & 0.20 & 2.82 \\
\hline Tyrosine (Tyr) & 3.17 & 3.02 & 3.17 & 3.02 & 3.10 & 0.08 & 2.58 \\
\hline Tryptophan (Try) & ND & ND & ND & ND & ND & ND & ND \\
\hline Phenylalanine (Phe) ${ }^{\mathrm{a}}$ & 4.05 & 3.88 & 4.05 & 3.71 & 10.92 & 12.10 & 10.81 \\
\hline Isoelectric point (pI) & 5.54 & 6.91 & 5.12 & 4.99 & 5.64 & 0.76 & 13.48 \\
\hline P-PER & 2.52 & 2.40 & 2.47 & 2.30 & 2.42 & 0.08 & 3.31 \\
\hline
\end{tabular}

${ }^{a}$ Essential amino acid; $\mathbf{p I}=$ Calculated isoelectric point; P-PER = Predicted protein efficiency ratio; $\mathbf{N D}$ = Not detected; SD = Standard deviation; CV = Coefficient of variation.

ratio (P-PER) ranged between $2.30-2.52 \mathrm{~g} / 100 \mathrm{~g}$ cp. This result is highly comparable to the $2.33 \mathrm{~g} / 100 \mathrm{~g}$ cp reported for Numida meleagis (eyes) [39], $2.62 \mathrm{~g} / 100 \mathrm{~g}$ cp (liver) and 2.32 $\mathrm{g} / 100 \mathrm{~g} \mathrm{cp}$ (heart) of Cricetomys gambianmus [40] and 2.6 $\mathrm{g} / 100 \mathrm{~g}$ cp for Clarias lazera [7], but lower in values than some plants food such as corn ogi (4.06 g/100g cp) [41]. The calculated isoelectric point (pI) derived from amino acids would assist in the prediction of the protein isolate of organic product. The pI values in the present study ranged between 4.99 in rice bran heat treatment to 6.91 sawdust smoking.

Parameters on the quality of protein of the samples are presented in Table 4 . The essential amino acid (with histidine) ranged between $40.25 \mathrm{~g} / 100 \mathrm{~g}$ cp for heat treatment using rice bran to $70.00 \mathrm{~g} / 100 \mathrm{~g}$ cp in sawdust smoking. The values obtained for rice bran and melon husk smoking are highly comparable with the value for the electric oven (control). The essential aromatic amino acid (EArAA) range suggested for infant protein of 6.8 to $11.8 \mathrm{~g} / 100 \mathrm{~g}$ сp [42] is slightly above $4.05 \mathrm{~g} / 100 \mathrm{~g}$ cp reported for electric oven and melon husk smoking which was the highest value among the different heat sources. The percentage ratio of EAA (with histidine) to the total amino acid (TAA) in the samples ranged between $46.85 \%$ in electric oven smoking to $59.83 \%$ in sawdust heat treatment. These values are very favourably comparable with $39 \%$ considered adequate for ideal protein food for infant, $26 \%$ for children and $11 \%$ for adults [42]. The EAA/TAA (\%) for the samples could be favourably compared with other animal protein sources such as $47.10 \%$ in Clarias lazera [7], 47.5\% for Tilapia quineensis [27] and $50 \%$ for egg [21]. The percentage of total neutral amino acid (TNAA) ranged from 56.03 in rice bran smoking to $66.40 \%$ in sawdust heat treatment, indicating that this formed the bulk of the amino acids. Percentage (\%) total acidic amino acid (TAAA) ranged from 19.67 in sawdust smoking to 26.23 in rice bran heat treatment which are far lower than \% TNAA while the percentage range in total basic amino acid (TBAA) is $13.93-18.02 \%$ which made them the third largest group among the samples. However, this is an indication that the protein is probably acidic in nature [30]. 
Table 4. Classification of Amino Acid Composition (mg/100g Crude Protein) of Smoked Clarias gariepinus

\begin{tabular}{|c|c|c|c|c|c|c|c|}
\hline \multirow[b]{2}{*}{ Amino Acid } & \multicolumn{4}{|c|}{ Heat Treatments } & \multirow[b]{2}{*}{ Mean } & \multirow[b]{2}{*}{ SD } & \multirow[b]{2}{*}{ CV\% } \\
\hline & $\begin{array}{c}\text { Electric } \\
\text { Oven }\end{array}$ & Sawdust & $\begin{array}{c}\text { Melon } \\
\text { Husk }\end{array}$ & $\begin{array}{l}\text { Rice } \\
\text { Bran }\end{array}$ & & & \\
\hline Total amino acid (TAA) & 93.92 & 117.14 & 86.58 & 85.10 & 95.69 & 12.83 & 13.41 \\
\hline Total Non-essential amino acid (TNEAA) & 49.92 & 47.05 & 45.77 & 44.85 & 46.90 & 1.91 & 4.07 \\
\hline$\%$ TNAA & 53.15 & 40.17 & 52.86 & 52.70 & 49.72 & 5.52 & 11.10 \\
\hline \multicolumn{8}{|l|}{ Total essential amino acid (TEAA) } \\
\hline With histidine & 44.00 & 70.09 & 40.81 & 40.25 & 48.79 & 12.38 & 25.37 \\
\hline Without histidine & 41.29 & 67.47 & 38.29 & 37.95 & 46.25 & 12.32 & 26.64 \\
\hline \multicolumn{8}{|l|}{$\%$ TEAA } \\
\hline With histidine & 46.85 & 59.83 & 47.14 & 47.30 & 50.28 & 5.52 & 10.98 \\
\hline Without histidine & 43.96 & 57.60 & 44.22 & 44.59 & 47.59 & 5.78 & 12.15 \\
\hline Essential aliphatic amino acid (EAAA) & 20.62 & 19.47 & 18.84 & 19.04 & 9.49 & 0.69 & 3.54 \\
\hline Essential aromatic amino acid (EArAA) & 4.05 & 3.88 & 4.05 & 3.71 & 10.92 & 12.10 & 10.81 \\
\hline Total neutral amino acid (TNAA) & 53.12 & 77.78 & 49.18 & 47.68 & 56.94 & 12.19 & 21.41 \\
\hline$\%$ TNAA & 56.56 & 66.40 & 56.80 & 56.03 & 58.95 & 4.31 & 7.31 \\
\hline Total acidic amino acid (TAAA) & 23.92 & 23.04 & 21.80 & 22.32 & 22.77 & 0.80 & 3.51 \\
\hline$\%$ TAAA & 25.47 & 19.67 & 25.18 & 26.23 & 24.14 & 2.61 & 10.81 \\
\hline Total basic amino acid (TBAA) & 16.88 & 16.32 & 15.60 & 15.10 & 15.98 & 0.68 & 4.25 \\
\hline$\%$ TBAA & 17.97 & 13.93 & 18.02 & 17.74 & 16.92 & 1.73 & 10.22 \\
\hline Total sulphur amino acid (TSAA) & 3.38 & 3.35 & 3.18 & 3.26 & 3.29 & 0.08 & 2.43 \\
\hline \% Cystine & 27.51 & 27.76 & 27.04 & 26.38 & 27.17 & 0.53 & 1.95 \\
\hline
\end{tabular}

SD = Standard deviation; $\mathbf{C V}=$ Coefficient of variation

Table 5. Amino Acid Composition (mg/100g Crude Protein) of Clarias gariepinus Smoked with Different Sources of Heat

\begin{tabular}{|c|c|c|c|c|c|c|c|c|c|}
\hline \multirow{2}{*}{ EAA } & \multirow{2}{*}{$\begin{array}{c}\text { PAAESP (g/100g } \\
\text { protein) }\end{array}$} & \multicolumn{2}{|c|}{ Electric Oven } & \multicolumn{2}{|c|}{ Sawdust } & \multicolumn{2}{|c|}{ Melon Husk } & \multicolumn{2}{|c|}{ Rice Bran } \\
\hline & & EAAC & AAS & EAAC & AAS & EAAC & AAS & EAAC & AAS \\
\hline Ile & 4.0 & 3.80 & 0.95 & 3.55 & 0.89 & 3.65 & 0.91 & 3.65 & 0.91 \\
\hline Leu & 7.0 & 7.32 & 1.05 & 7.02 & 1.00 & 7.20 & 1.03 & 6.80 & 0.97 \\
\hline Lys & 5.5 & 7.78 & 1.41 & 7.40 & 1.35 & 7.21 & 1.31 & 7.02 & 1.28 \\
\hline Met + Cys (TSAA) & 3.5 & 3.38 & 0.97 & 3.35 & 0.96 & 3.18 & 0.91 & 3.26 & 0.93 \\
\hline Phe + Tyr & 6.0 & 7.22 & 1.20 & 34.90 & 5.82 & 7.22 & 1.20 & 6.73 & 1.12 \\
\hline Thr & 4.0 & 4.69 & 1.17 & 4.30 & 1.08 & 4.00 & 1.00 & 4.28 & 1.07 \\
\hline Try & 1.0 & nd & na & nd & na & $\mathrm{Nd}$ & na & nd & na \\
\hline Val & 5.0 & 4.81 & 0.96 & 4.60 & 0.92 & 3.99 & 0.80 & 4.31 & 0.86 \\
\hline Total & 36.0 & 39.00 & 7.71 & 65.12 & 12.02 & 36.45 & 7.16 & 36.05 & 7.14 \\
\hline
\end{tabular}

EAA = Essential amino acid; PAAESP = Provisional amino acid (egg) scoring pattern;

EAAC = Essential amino acid composition (Table 3); AAS = Amino acid scores;

nd = Not determined; $\mathbf{S D}=$ Standard deviation; $\mathbf{C V}=$ Coefficient of variation;

na $=$ Not applicable; Source $=$ Belschant et al. [43]. 
The essential amino acid scores (EAAS) based on the provisional amino acid scoring pattern [18] are shown in Table 5. The fish sample smoked with sawdust is favourably comparable to the electric oven (control) smoking and is rated high when compared with melon husk and rice bran heat treatment. However, with exception of Leu in sawdust smoking; Lys, Phe + Tyr and Thr in sawdust and electric oven heat treatment, supplementation with essential amino acids will be required for all the samples such as Ile, Met + Cys (TSAA), Leu in electric oven smoking, Thr and Leu in melon husk and rice bran heat treatments. Tryptophan was not determined; it has been reported that the essential amino acids most often acting in a limiting capacity are Met (and Cys), Lys and Try [37]. However, the first limiting amino acid (LAA) for all the smoked fish samples in this study was Ile for electric oven and sawdust heat treatments; Val for melon husk and rice bran smoking (Table 5). Levels of CV\% ranged from 2.08 in Met to 13.48 in pI (Table 3).

\section{CONFLICT OF INTEREST}

The author(s) confirm that this article content has no conflicts of interest.

\section{ACKNOWLEDGEMENT}

None declared.

\section{REFERENCES}

[1] Adeyeye EI. Amino acid composition of three species of Nigerian fish: Clarias anguillaris, Oreochromis niloticus and Cynoglossus senegalensis. Food Chem 2009; 113(1): 43-6.

[2] Oluwaniyi OO, Dosumu OO. Effect of local processing methods (boiling, frying and roasting) on the amino acid composition of four marine fishes commonly consumed in Nigeria. Food Chem 2010; 115: 51-7.

[3] Clucas IJ. Fish Handling, Processing and Preservation in Tropics. Great Britain: Tropical Product Institute, 1981; p. 144.

[4] Madison A, Machell K, Adams L. Fish Processing Food Cycle Technology Source Book. London: International Technology Publicans, 1993; p. 66.

[5] Osuji FNC. Influence of traditional handling methods on the quality processed fish in Nigeria. Conference on Handling, Processing and Marketing of Topical Fish, 5-9 $9^{\text {th }}$ July, 1976. London, UK 1976; pp. 319-22.

[6] Garrow JS, James WPT. Human Nutrition and Dietetics. London: Churchill Living Stone, 2000; p. 84.

[7] Aremu, MO, Ekunode, OE. Nutritional evaluation and functional properties of Clarias lazera (African catfish) from river Tammah in Nasarawa State, Nigeria. Am J Food Technol 2008; 3(4): 264-74.

[8] Eyo AA. Post harvest Losses in the Fisheries of Kainji. Nigeriangerman Kainji Lake Fisheris Promotion Project Technical Report Series 5, 1997; p. 75.

[9] Oyarekua MA, Ketiku AO. The nutrient composition of the African rat. Adv J Food Sci Technol 2012; 2(6): 318-24.

[10] Buton MN. The breeding biology and earl development of Clarias gariepinus (Pisces: Clariidae) in Lake Sibaya, South Africa, with a review of breeding in species of the sub genus Clarias. Trans Zool Soc 1979; 35: 1-45.

[11] Sule OD, Adikwu IA. Determination of the optimum latency period for Clarias gariepinus in arid zone of Nigeria. Biosci Res Commun 2002; 12: 261-7.

[12] Diyaware MY, Haruna AB, Sule OD. Determination of Latency time using dry carp pituitary extraction for Clarias gariepinus in the arid zone of Nigeria. PAT 2007; 3(1): 104-11.
[13] Ayinla OA, Nwadukwe A. The effect of season on the controlled propagation of the African catfish (Clarias gariepinus). Czech J Anim Sci 1990; 48: 181-90.

[14] AOAC. Official methods of analysis. $13^{\text {th }}$ ed. Washington DC: Association of Official Analytical Chemist 1980.

[15] Aremu MO, Olaofe O, Basu SK, Abdulazeez G, Acharya SN. Processed cranberry bean (Phaseolus coccinus) seed flours for African diet. Can J Plant Sci 2010; 90: 719- 28.

[16] Adeyeye EI, Akinyeye RO, Ogunlade I, Olaofe O, Bolawade JO. Effect of farm and industrial processing on the amino acid profile of cocoa beans. Food Chem 2010; 118: 357-63.

[17] James CS. Analyticval Chemists of Foods. New York, NY: Chapman and Hall 1996.

[18] FAO/WHO. Protein Quality Evaluation Report of Joint FAO/WHO Expert Consultation. USA: FAO Food and Nutrient 1991.

[19] Olaofe O, Akintayo ET. Prediction of isoelectric points of legume and oil seed proteins from their amino acid composition. J Technol Sci 2000; 4: 49-53.

[20] Paul AD, Southgate AT, Russel J. First Supplement to McCane and widdowson's the Composition of Foods. London: HMSO 1976.

[21] FAO/WHO. Protein Quality Evaluation Report of Joint FAO/WHO Expert Consultation, FAO Food Nutrition. Paper No. 51, Rome 1990.

[22] Alsmeyer AH, Cunningham, AE, Happich ML. Equation to predict (PER) from amino acid analysis. Food Technol 1974; 28: 34-8.

[23] Nieman DC, Butterworth DE, Nieman CN. Nutrition. USA: Wm C Brown Publishers Dubuque, 1992; pp. 237-312.

[24] Paul AA, Southgate DAT. McCance and Wieldowson's. The Compositio of Foods. $4^{\text {th }}$ ed. UK: London Her Majesty's Stationary Office, 1978; pp. 227-28.

[25] Kilgour OFG. Mastering Nutrients. London, UK: Macmillan Education Ltd. 1987; pp. 85-6.

[26] Ogbonnaya C, Ibrahim MS. Effects of drying methods on proximate compositions of catfish (Clarias gariepinus). World J Agric Sci 2009; 5(1): 114-6.

[27] Aremu MO, Olonisakin A, Opaluwa OD, Mohammed Y, Salau RB. Nutritional qualities assessment of tilapia fish (Tilapia quineensis). Ind J Multidiscip Res 2007; 3(3): 443-56.

[28] Kumolu-Johnson CA, Ndimele PE. Effect of salting, bringing and sundrying on the shelf-life of Clarias gariepinus (LACEPEDE). J Res Rev Int Sci 2001; 2: 21- 5.

[29] Aremu MO, Bamidele TO, Nweze CC, Idris IM. Chemical evaluation of pride of barbados (Caesalpinia pulcherrima) seeds grown in Gudi, Nasarawa State, Nigeria. Int J Chem Sci 2011; 5(1): 29-34.

[30] Aremu MO, Olaofe O, Akintayo ET. A comparative study on the chemical composition and amino acid composition of some Nigerian underutilized legume flours. Pak J Nutr 2006; 5(1): 34-8.

[31] Mishra S, Dwivedi SP, Singh RB. A review on epigenetic effect of heavy metal carcinogens on human health. Open Nutra J 2010; 3: 188-93.

[32] Fleck H. Introduction to Nutrition. $3^{\text {rd }}$ Eds. New York, USA: Macmillan, 1976; pp. 207-19.

[33] Shills ME. Magnesium. In: Fleck H, Ed. Introduction to Nutrition $3^{\text {rd }}$ ed. New York, USA: Macmillan Publishing Co. Inc. 1973; p. 215.

[34] Shills MYG, Young VR. Modern Nutrition in Health and Disease. In: Nieman DC, Butterworth DE, Nieman CN, Eds. Nutrition. Dubuque IA: WMC Brown Publishers, 1992; pp. 176-282.

[35] Marten CR, Anderson AB. Practical Food Inspection. $9^{\text {th }}$ ed. Alesbury: Itaze II Watson and Viney Ltd. 1975; p. 232.

[36] Oshodi AA, Olaofe O, Hall GM. Amino acid, fatty acid and mineral composition of pigeon pea (Cajanus cajan). Int J Food Sci Nutr 1993; 43: 187-91.

[37] Adeyeye EI. The chemical composition of liquid and solid endosperm of ripe coconut. Orient J Chem 2004; 20(3): 471-6.

[38] Bingham S. Dictionary of Nutrition. London: Barrie and Jenkins, 1997; pp. 76-181.

[39] Adeyeye EI, Aremu MO. Comparative evaluation of the amino acid profile of the brain and eyes of guinea fowl (Numida meleagris) hen. Open Nutra J 2010; 3: 220-6. 
[40] Adeyeye EI, Aremu MO. Amino acid composition of two fancy meats (liver and heart) of African giant porch rat (Cricetomys gambianus). Orient J Chem 2010; 27(4): 1409-19.

[41] Oyarekua MA, Eleyinmi AF. Comparative evaluation of the nutritional quality of corn, sorghum and millet ogi prepared by modified traditional technique. J Food Agric Environ 2004; 2: 94-9.
[42]

FAO/WHO/UNU. Energy and Protein Requirements. WHO Technical Report Series. No. 275, Geneva: WHO 1985; p. 204.

[43] Belschant AA, Lyon CK, Kohler GO. Sunflower, sesame and castor proteins. In: Price NW, Ed. Food Protein Sources, Cambridge, UK: University Press, 1975; pp. 79-104.

Received: April 01, 2013

(C) Aremu et al.; Licensee Bentham Open.

This is an open access article licensed under the terms of the Creative Commons Attribution Non-Commercial License (http://creativecommons.org/licenses/by-nc/3.0/) which permits unrestricted, non-commercial use, distribution and reproduction in any medium, provided the work is properly cited. 